\title{
The Most Significant International Groups and Institutions Taking Part in the Fight against Money Laundering and Financing Terrorism
}

\author{
Attila BUGYÁKI ${ }^{1}$
}

\begin{abstract}
In the first part of the two-piece study the author examined the emergence of the organizational system against money laundering in the European Union. In this second part the daily practice of the war against money laundering is studied, introducing the major international groups and institutions which, with their activities, take active part in the fight against money laundering, financing terrorism, and other related crimes.
\end{abstract}

Keywords: money laundering, financing of terrorism, international organizations, Financial Action Task Force on Money Laundering, FATF-Style Regional Bodies

\section{The Daily Practice of the Fight against Money Laundering}

It is necessary to study the daily practice of the fight, after introducing the emergence of the international institutional system fighting against money laundering and terrorism in the first part. In this context those major groups and institutions are introduced which, with their activities, take active part in the fight against money laundering, financing terrorism, and other related crimes. The committed institutions, according to their activities and programmes, can be divided into three major groups. ${ }^{2}$ The first and most important is the Financial Action Task Force on Money Laundering (FATF), the second one, based on a similar pattern is the later established and currently embracing 9 members, i.e. FATF-Style Regional Bodies (FSRBs). The third group includes: the collaborating international institutions and law enforcement authorities which, with their activities - directly or indirectly-effectively contribute to achieve success.

\section{Financial Action Task Force on Money Laundering (FATF)}

The basis for founding the international institution FATF (officially in French: Groupe d'action financière sur le blanchiment des capitaux - GAFI) was provided by the Vienna Convention, created by seven countries - Canada, Germany, Italy France, Japan, the United Kingdom and the United States - in Paris on 16 July 1989. To the founding G73 countries further eight

\footnotetext{
Ph.D. student, National University of Public Service, Doctoral School of Military Sciences; e-mail: attila. bugyaki@freemail.hu

2 It is important to note that, in addition to the above, representatives of the civil sphere are also taking part in preventing the increasing security challenges during the fight against money laundering and terrorism-taking advantage of business opportunities_-organizing different professional educational trainings, forums, events, conferences, seminars and webinars, which creates an individual category. One of the most acknowledged international member organization is the Association of Certified Anti-Money Laundering Specialists (ACAMS), founded in 1989, which is based in Miami and has offices in several capitals around the world.

3 G7 is the abbreviation of the Group of Seven, which was founded in 1976 by the seven most developed countries to increase political and economic collaboration.
} 
countries joined in two years, and as a result of further development, another 31 countries in 2000, and today the Paris based institution has 37 members. ${ }^{4}$ The members, besides each other, are in daily contact with several other international and regional organizations, which also have interests in the fight against money laundering and financing terrorism. According to the initial plan the workgroup was supposed to cooperate for a predetermined period of time, but due to the successes, the cooperation in the following years was prolonged, and currently the organization is mandated until 2020.

The FATF is such an independent, government-close, specially authorized, particular and collaboration Action Group, which, working under the aegis of the Organisation for Economic Co-operation and Development (OECD), ${ }^{5}$ determines the strategy and main elements of the fight against money laundering and terrorism. [3] Its legal entity is to be considered as qualified, but we cannot state that the situation is the same relative to all the other countries, without recognition. Since it is not supranational, it creates no legal sources, but during its activities, it creates national and EU-recommendations, which are used as international standards in more than a thousand countries. Its duty is creating the international standards for the fight against money laundering and financing terrorism, studying the related legislation, practice and measures of the member countries, monitoring and qualifying the development and harmonization of these measures in favour of the international collaboration. [4: 112-116]

The Financial Action Task Force on Money Laundering elaborated its recommendations about the unified, internationally acknowledged anti-money laundering principle system in 40 theses, which legally is not obligatory, but the acknowledging countries adjusting their national legislation to this, which is an essential basis for creating the international cooperation. The recommendations emphasize the importance of multilateral cooperation, the need for consolidating the international legal systems, the roles of financial institutions and financial authorities, and the importance of international informational flow. [5: 2] In October 2001 the FATF elaborated initially 8, then further one recommendation in October $2004-9$ in total-against financing terrorism. ${ }^{6}$ These recommendations - reacting to new and evolving danger-are periodically reconsidered, and according to this are reformed so that they can be initiated world-wide. For this theoretical and practical elaboration, the organization involves three work groups, dealing with independent, legal, financial and foreign relations, so the formed theses ensure a wide and flexible context for the countries to adapt according to their

4 The FATF currently comprises 35 member jurisdictions (Argentina, Australia Austria, Belgium, Brazil, Canada, China, Denmark, Finland, France, Germany, Greece, Hong Kong [China], Iceland, India, Ireland, Italy, Japan, Luxembourg, Malaysia, Mexico, the Netherlands, New Zealand, Norway, Portugal, the Republic of Korea, the Russian Federation, Singapore, South Africa, Spain, Sweden, Switzerland, Turkey, the United Kingdom, the United States) and 2 regional organisations (the European Commission, the Gulf Co-operation Council), representing most major financial centres in all parts of the globe. [1]

5 The legal predecessor of the Paris based international economic organization was founded by 20 countries on 16 April 1948, and it is called Organization for European Economic Cooperation (OEEC), with the goal of organizing and monitoring the mutual restoration programme, the proper division of aids and restoring the economy after the war-according to the Marshall Plan. It has been operating in its current form since 30th September 1961 and mainly takes part in harmonizing the economic, commercial and financial activities. Hungary has been a member since 1996. [2]

6 Initially the FATF was established to fight against money laundering, but after the terror attacks against the U.S. on 11 September 2001, the world's leading countries agreed with the European Union-using the experiences of the group and its achievements - and they decided to extend the role of the Action Group with a further 9 Special Recommendations, which are especially focused on the effective fight against financing terrorism. 
capabilities. The FATF, based on the $40+9$ recommendations and the method system for monitoring creates a report about the member countries periodically. The country-monitoring is discussed by the representatives of the countries on a plenary assembly, which serves as a means for making political-diplomatic pressure. The plenary assembly is used for electing the current president as well, whose mandate is valid for one year.

The FATF elaborated its latest international recommendations for the fight against money laundering and financing terrorism, meeting the standards and the new methods for evaluating the efficiency of the member countries in June 2017, which focuses on technical adequacy and efficiency. ${ }^{7}$ Although the events of the past years required changes, the basic principles have not changed.

The members control the execution of the recommendations in two ways, which complement each other simultaneously. The first is the self-evaluating system, where each member country is inspecting its own situation, and the second one is the system of mutual evaluation, where the situation of a member country is evaluated and monitored by the professionals of another FATF member country. The goal of the monitoring is to unveil those areas - besides the objective and comprehensive picture - that still require changes and developments in the future.

For creating pressure, the members created the category of Non-Cooperative Countries and Regions, with the context of assigning those 25 criteria, ${ }^{8}$ based on which the non-cooperative countries can be identified. ${ }^{9}$ The four established regional groups are: American, Asian/ Pacific, European and African/Middle East groups; the countries which do not meet these criteria are on a blacklist. ${ }^{10}$

\section{FATF-Style Regional Bodies (FSRBs)}

Since the FATF does not wish to accept further members to join, instead it is urging the formation of regional organizations. As a result of this and the severing proclamations and action plans published by the United Nations - using the successes of the FATF — several international regions have created their own institutions for fighting against money laundering and financing terrorism, which are called FATF-Style Regional Bodies (FSRBs). [9]

7 The FATF published the recommendations for the first time in 1990, then revised it in 1996, 2001 and 2012 , which was last updated in June 2017. [6]

$8 \quad$ "The initiative is based on the foreign taxation strategy of the EU, and will complement the ongoing efforts focusing on the prevention of tax evasion. Creating the EU list, the goal is to create and present those norms, which are already obligatory in the EU-said Edward Scicluna. The non-EU countries and regions are to be scanned. They will be on the list of the non-cooperative countries, if they do not meet the minimum requirements of the EU during the scanning. The Council is due to finalize the list of non-cooperative jurisdictions before the end of 2017." [7]

9 On the actual list—several jurisdictions' examinations are still in process—because of their high risks and the lack of their strategic obligations, nine countries are present: Bosnia and Herzegovina, the Democratic People’s Republic of Korea, Ethiopia, Iran, Iraq, Syria, Uganda, Vanuatu and Yemen. [8]

10 Hungary is committed to fight against money laundering and terrorism, but since the Group does not wish to extend in this region — they would rather support the fight on a regional and national level—Hungary is not a member of the FATF. Despite this fact, the Hungarian government has indicated its willing to join. Hungary — as a doubtful glory_-was on the blacklist in June 2001 for a short while, since it was possible to make anonymous deposits on infinite number of bank accounts up to a limit of 2,000,000 HUF at the time, so the financial institutions were unable to identify the owners of the bank accounts. After legal changes, Hungary was removed from this list in June 2002. 
The mutual traits of the individual Bodies are the voluntary, cooperative origination based on the members' agreements, and due to this - as they are not obliged by international contracts - they are to be seen independent. According to this, the members-aspiring to adopting the international and FATF-standards - define their activities and regulations via consensus, which cannot be in contrast with their cultural values and constitutional legal system.

Although the FATF and the FSRBs are individual organizations, independent from each other, they cooperate acknowledging and helping each other's work efficiently to achieve their common goal, repelling money laundering, the financing of terrorism, preventing proliferation and identifying and successfully treating the increasing threats in the financial system. Achieving this, besides creating unified international legal context, they focus on developing the national policies and methods for increasing the collaboration between the member countries. As an evaluating body, during its work, they use mechanisms like the FATF, and the results are constantly evaluated, monitored and shared with each other in favour of mutual aid. In favour of the most efficient compliance and use of the international and FATF-standards, besides technical aiding, the members actively support each other in execution as well. Furthermore, the members are constantly taking part in developing the FATF-standards, harmonizing the collaborative programmes, researches and workshops. Today there are nine individual, but parallel working FATF-Style Regional Bodies in the world, which, in connection with FATF, create a comprehensive and global network in the fight against money laundering and financing terrorism.

\section{Moneyval}

One of the oldest and most important regional programmes was founded by the European Commission in 1997 called Select Committee of Experts on the Evaluation of Anti-Money Laundering Measures (PC-R-EV). The tasks of the organization was extended in 2002 to fight against financing terrorism, thus - after its name did not reflect properly the new functions - was renamed as Committee of Experts on the Evaluation of Anti-Money Laundering Measures and the Financing of Terrorism; Moneyval in short. The role of the commission founded by 21 members_-which today has 47 constant and 6 monitoring members ${ }^{11}$-is to develop the skills of national authorities for the fight against money laundering and financing terrorism. In this context, it controls its own and the mutual surveys and evaluations with the members, and makes recommendations for realizing more effective measures and collaboration, and organizes events and trainings (e.g. typological seminars), whose purpose is sharing the professional knowledge. [11] Furthermore, since the Moneyval is a crime-focused subcommittee of the European Commission, it focuses greatly on jurisdiction in the context of

11 Permanent Members: Albania, Andorra, Armenia, Austria, Azerbaijan, Belgium, Bosnia and Herzegovina, Bulgaria, Croatia, Cyprus, the Czech Republic, Denmark, Estonia, Finland, France, Georgia, Germany, Greece, Hungary, Iceland, Ireland, Italy, Latvia, Liechtenstein, Lithuania, Luxembourg, Macedonia, Malta, Moldova, Monaco, Montenegro, the Netherlands, Norway, Poland, Portugal, Romania, the Russian Federation, San Marino, Serbia, Slovakia, Slovenia, Spain, Switzerland, Sweden, Turkey, Ukraine, the United Kingdom. In addition, observer status: Canada, the Holy See, Israel, Japan, Mexico, the United States of America. Since Hungary is a member of Moneyval as well, it has to meet the requirements of the recommendations by respecting the FATF regionally, and make scanning possible for the international organizations against money laundering and financing terrorism. [10] 
the fight against money laundering. "The goal of its function is to evaluate the individual member countries' legislation, practice and measures related to money laundering-based on the methods of FATF-and harmonizing and developing these measures, fostering international collaboration." [12] During the examination of each country, the delegate of the Moneyval evaluates the specific country's legal system and the Financial Intelligence Units' (FIU) activities on a few days long personal visit. It is discussed and accepted on the plenary assemblies, held three times every year. [13: 46] The member countries are authorized to send three persons to the Committee. The Moneyval became an Associate Member of the FATF in June 2006.

\section{Caribbean Financial Action Task Force (CFATF)/ Grupo de Acción Financiera del Caribe (GAFIC)}

The Caribbean Financial Action Task Force - with 25 members $^{12}$ - was the first one to establish after FATF, in May 1990, on one of the Lesser Antilles islands, Aruba. [15] After their establishment, the representatives of the Caribbean and Middle-American countries elaborated a special, 19-theses recommendation [16] in favour of repelling money laundering, which amended the earlier 40 FATF Recommendations. To increase efficiency, it introduced a special regional supporting and training strategy for the members. It holds its plenary assemblies twice a year, where one representative from each country takes part. Its highest body is the Committee, led by the president. With its basic activities it focuses on new kinds of challenges, like increasing terror threats, illegal gambling, human trafficking and fighting the risks of digital currencies. The CFATF/GAFIC became an Associate Member of the FATF in 2006.

\section{Asia/Pacific Group on Money Laundering (APG/APGML)}

The organization was founded in February 1997 by 13 countries-some were already members of the FATF-in Bangkok. [17] The first assembly after the establishment was held in Tokyo in 1998, and after that plenary assemblies were held at least annually, where, besides the most important decisions, they elaborated work programmes, which were adapted to the strategic plans elaborated every 4 years. The current strategic plan, valid 2016-2020, defines the organization to function as a regional "government" that focuses its task on moderating and repelling money laundering, financing terrorism and the spread of mass destruction weapons in the Pacific area, taking the international and national standards into account. [18] To accomplish these missions, it has three objectives:

- to work as an efficient multilateral organization, that supports enforcing and executing the FATF-standards and the work against money laundering and financing terrorism;

- to collaborate with the members to understand the risk environment of money laundering and financing terrorism, in favour of executing FATF-standards;

- to evaluate the enforcing and execution of FATF-standards, and react to the changes.

12 Anguilla, Antigua and Barbuda, Aruba, the Bahamas, Barbados, Belize, Bermuda, the British Virgin Islands, the Cayman Islands, Curaçao, Dominica, El Salvador, Grenada, Guyana, the Republic of Haiti, Jamaica, Montserrat, Saint Kitts and Nevis, Saint Lucia, Saint Maarten, Saint Vincent and the Grenadines, Suriname, the Turks and Caicos Islands, Trinidad and Tobago, Venezuela. [14] 
Besides, they regularly organize seminars on the new methods and techniques of money laundering and financing terrorism. The group consists of 41 members ${ }^{13}$ - which are divided into 5 groups in order of the efficient control: Northern Asia, South-East Asia, South Asia, Pacific region, CANZUS ${ }^{14}$ - and several international and regional observers. The APG became an Associate Member of the FATF in 2006.

\section{Eastern and Southern Africa Anti-Money Laundering Group (ESAAMLG)}

The Eastern and Southern Africa Anti-Money Laundering Group was founded in August 1999 in Arusha (Tanzania) and it has 18 members. ${ }^{15}$ The Group's decisions are made and accepted on the at least annually held assembly by the Ministerial council. [21] The Council accepted the fourth 3 yearlong strategic plan between 2017-2020, whose goal, besides confirming the previous tasks, is increasing the efficiency level of member countries, to become a more efficient member of the global FATF network. [22] To increase the transparency, it created risk-based evaluations, analysis and surveys, and constantly monitors the new trends in money laundering and financing terrorism. Besides the above, it greatly focuses on strengthening the collaboration internationally and regionally between the member countries, as well as the possibility of extension. The ESAAMLG became an Associate Member of the FATF in June 2010.

\section{Inter-Governmental Action Group Against Money Laundering in West Africa/ Groupe Intergouvernemental d'Action contre le Blanchiment d'Argent en Afrique de l'Ques (GIABA)}

The Economic Community of West African States (ECOWAS) ${ }^{16}$ was founded by 16 countries $^{17}$ in December 1999, based in Dakar. [25] Its main tasks, besides prevention are to reinforce and harmonize the capacity of the West African Region, which makes it easier to fit the international standards in controlling the money laundering and financing terrorism. The measures created in this context provide efficient security against crimes committed against banking and financial systems. The GIABA became an Associate Member of the FATF in June 2010.

13 Afghanistan, Australia, Bangladesh, Bhutan, Brunei Darussalam, Burma, Cambodia, Canada, China, the Cook Islands, Fiji, Hong Kong (China), India, Indonesia, Japan, Laos, Macau (China), Malaysia, Maldives, the Marshall Islands, Mongolia, Nauru, Nepal, New Zealand, Niue, Pakistan, Palau, Papua New Guinea, Philippines, Samoa, Singapore, Solomon Islands, South Korea, Sri Lanka, Taiwan, Thailand, Timor Leste, Tonga, the United States, Vanuatu, Vietnam. [19]

14 The word CANZUS is the abbreviation of four countries: Canada, Australia, New Zealand and the United States.

15 Angola, Botswana, Ethiopia, Kenya, Lesotho, Madagascar, Malawi, Mauritius, Mozambique, Namibia, Rwanda, Seychelles, South Africa, Swaziland, Tanzania, Uganda, Zambia, Zimbabwe. [20]

16 The ECOWAS was founded with signing the Lagos Agreement on 28 May 1975, with the purpose of fostering the integration of the economic region. In spite of this commerce among the members, in the context of economic and monetary union was standardized. [23]

17 The Republic of Benin, Burkina Faso, the Republic of Cape Verde, the Republic of Côte d'Ivoire, the Republic of the Gambia, the Republic of Ghana, the Republic of Guinea, Guinea-Bissau, the Republic of Liberia, the Republic of Mali, the Republic of Niger, the Federal Republic of Nigeria, São Tome and Principe, the Republic of Senegal, the Republic of Sierra Leone, the Togolese Republic. [24] 


\section{Task Force on Money Laundering in Central Africa/ Groupe d'Action contre le Blanchiment d'Argent en Afrique Centrale (GABAC)}

The Group - which is a determinative organization of the Economic and Monetary Community of Central Africa - was founded in early 2000 with 6 founding members ${ }^{18}$ with the authorization to fight against money laundering and financing terrorism with executing FATF-standards and evaluating their execution. [27] Its tasks are-parallel with technical support and international collaboration-identifying money laundering methods and techniques used by terrorist groups and their supporters, exploring their traits, analysing, evaluating and sharing them. In October 2015, the FATF recognised GABAC as an FSRB and admitted it as an associated member.

\section{Financial Action Task Force on Money Laundering of Latin America/ Grupo de Acción Financiera de Latinoamérica (GAFILAT)}

The Financial Action Task Force on Money Laundering of Latin America was founded in December 2009 by 9 members $^{19}$ in Cartagena de Indias (Columbia); later full members joined: Mexico (2006), Costa Rica, Panama (2010), Cuba (2012), Guatemala, Honduras, Nicaragua (2013) and the Dominican Republic (2016). [29] The-today having 17 members-Argentine-based regional society was first established as Financial Action Task Force on Money Laundering in South America (Grupo de Acción Financiera de Sudamérica, GAFISUD) which was changed on the plenary assembly in July 2014, since the new name reflected better its extension to all Latin American countries. During its activity, besides independency, accuracy, objectivity, quality and keeping deadlines, it is exclusively focused on enforcing, executing and monitoring the 40 FATF Recommendations and the 9 Special Recommendations, and ensuring the comprehensive communication and mutuality, which includes making the documents known as widely as possible. [13: 49] GAFILAT became an Associate Member of the FATF in 2006.

\section{Eurasian Group on Combating Money Laundering and Financing of Terrorism (EAG)}

The Group embracing the Eurasian Region was founded in October 2004 by 9 members ${ }^{20}$ in Moscow. [31] The main purpose was to repel money laundering and financing terrorism focused into the Eurasian Region, as well as the efficient and comprehensive repelling of economic crimes and with increasing transparency the corruption decreases pro rata, just like the likeliness of investments in the region. In favour of this, the Group provides help to the members in adapting, using and developing the FATF-standards, which makes it easier and simpler to cooperate in the key areas. During its work - using the context of communications and collaboration - it makes mutual evaluation, typological research, comprehensive advising and technical support according to the international standards, to reduce the risks.

\footnotetext{
Cameroon, Central African Republic, Chad, Equatorial Guinea, Gabon, the Republic of the Congo. [26]

Argentina, Bolivia, Brazil, Chile, Colombia, Ecuador, Paraguay, Peru, Uruguay. [28]

Belarus, China, India, Kazakhstan, Kyrgyzstan, Russia, Tajikistan, Turkmenistan, Uzbekistan. [30]
} 
A. BUGYÁKI: The Most Significant International Groups...

The recommendations, based on the above are used to increase efficiency and development. The EAG became an Associate Member of the FATF in June 2010.

\section{Middle East and North Africa Financial Action Task Force (MENAFATF)}

The organization was founded in November 2004 with the collaboration of 14 countries, based in the capital of the Bahrain Kingdom, Manama. [32] The Group's goal-extended to 19 members $^{21}$ today - is to set up an efficient system in the region, which is capable to stand against money laundering, financing terrorism and spreading mass destruction weapons, with accepting and executing the FATF-standards and the UN agreements. For this goal, besides a strong collaboration, it is obligatory to increase the enforcement of norms, research of typologies, identify the regional questions, share the experiences and elaborate solutions. The MENAFATF became an Associate Member of the FATF in June 2007.

\section{Collaborating International Institutions and Law Enforcement Authorities}

These organizations and authorities_although they are not members of the FATF—also take part in the fight against money laundering and financing terrorism on a daily basis. Their role is important, as they are actively and effectively taking part in the prevention of global crime with their action programmes, shared information and cooperation.

\section{Egmont Group}

The Egmont Group, founded in 1995 in Brussels - currently having 156 members [34] — is a committed international professional organization, which is important because of ensuring the information flow among the members. [35] The independent, voluntary national office's main tasks are receiving, analysing and forwarding the decisive financial information, which are connected to several crimes and are important in the fight against money laundering. [36] In favour of the purpose, the member countries started establishing their own Financial Intelligence Units (FIU), ${ }^{22}$ which are basically fostering, ensuring and developing the communication between the members. During their work - after processing, analysing and evaluating the work - they filter suspicious financial transactions which may be connected to money laundering activities. The individual financial investigator offices are in constant connection with important governmental and private finance institutions, law enforcement authorities and foreign FIU units, from whom they may claim data and information, according to international agreements. ${ }^{23}$ The inner information flow is ensured by a specially developed, internet-based secret computer software, ${ }^{24}$ which helps the professionals analyse

21 Algeria, Bahrain, Egypt, Iraq, Jordan, Kuwait, Lebanon, Libya, Mauritania, Morocco, Oman, Palestine, Qatar, Saudi Arabia, Sudan, Syria, Tunisia, the United Arab Emirates, Yemen. [33]

22 According to the EU Council decree elaborated on 17 October 2000 the FIU is: "A central, national unit which, in order to combat money laundering, is responsible for receiving (and to the extent permitted, requesting), analyzing and disseminating to the competent authorities, disclosures of financial information which concern suspected proceeds of crime or are required by national legislation or regulation.” [37: 124]

23 The members in specific cases — with the obligation of justification — can limit, or can even deny providing information, if it offends an ongoing investigation or the interests of the nation.

24 Egmont Secure Web 
the information with comparing the great amount of partial information. On the annual conference they inform each other about the results, experiences and cross-check about the further collaborations. Hungary joined the group on 16 December 2007, and became official member a few months later, on 10 March 2008. ${ }^{25}$

\section{FIU.net}

The FIU.net is a decentralized computer network initially founded by 5 Financial Intelligence Units-France, Italy, Luxembourg, the Netherlands, the United Kingdom-in 1999. According to the 1999 European Council Tampere decision FIU.net was founded under the aegis of Europol with the purpose of ensuring the efficient and uninterrupted information and data flow between the FIU units during the fight against money laundering and financing terrorism. [39] To the initiative, besides the Netherland Security and Law Enforcement Ministry, several EU members joined later voluntarily, providing a wider international opportunity to stand against crimes. The system's work is based on the obligation of the party managing money or other value from unusual or suspicious source to report the transaction to the national FIU unit, which, after scanning, in case of reasonable suspicion of money laundering or financing terrorism, immediately forwards it to the proper national authority for prosecution. During the measure the members, besides enforcing security are entitled to share information among each other. Besides the information flow, a further advantage is that the FIU units can compare the collected financial data with the Europol central criminal records, ensuring the unveiling of relations and connections, making faster reaction possible. The maintenance and development of FIU is today totally financed from the Europol's budget-counter to the previous support of the European Committee.

\section{Group of International Finance Centre Supervisors (GIFCS)}

The Group was established in October 1980 by the initiation of the Basel Bank Supervision Commission, called Offshore Group of Banking Supervisors which, in the past decades, greatly contributed to the Basel Statements and to the introduction of the FATF recommendations. [40] In March 2011 it changed its name to its current form-reflecting its extended roles. Although it manages similar tasks as FSRB, it is not a member of any Regional Syndicate. In 2002 it elaborated its own reference value system for creating regulation contexts and supervision practices called Trust and Company Service Providers (TCSP), which was revised in October 2014 extended with the earned experiences, and is used as a standard, enforced on its members. Its purpose is to create a global financial stability, the border-crossing supervision of banking and financial services and forming an efficient collaboration with the international institutions, and enforcing, fostering and inciting the members to fight against money laundering, financing terrorism and the spread of mass destruction weapons. During the execution of its tasks, it aspires to use the best practices and norms, developing them, increasing transparency, sharing collective and mutual professional knowledge, organizing

25 In Hungary, between 2004-2007, the police (National Investigational Office, Anti-Money Laundering Division) since 15 December 2007 the National Tax- and Custom Office Law Enforcement HQ (Financial Information Division) takes care of tasks related to money laundering. Note: until 31 December 2010 the latter was called Custom and Financial Police Central Law Enforcement HQ. [38] 
forums and consultations, extending the membership with members with similar interests, and increasing the capacity, reaching the most positive results when negotiating with affected third parties. The currently 19 members ${ }^{26}$ of the association, owning global international bank means, owns 10 percent of the market. [42]

\section{European Police Office (Europol)}

The Hague-based international organization founded in 1999 is the main institution for the police collaboration in the EU. [43] The purpose of the professionally working organization $^{27}$ is to produce results in the area of serious forms of crimes and organized crime in the context of an efficient collaboration, and creating a more secured Europe. During managing its tasks-due to the excellently trained professional staff and the humongous technical analysing capacity - they provide local support and information to the members. Dominant operational specializations are: drugs, weapons trafficking, illegal migration, terrorism, Euro counterfeiting, cybercrime, tax evasion and fight against money laundering.

\section{European Anti-Fraud Office/Office Européen de Lutte Antifraude (OLAF)}

The OLAF, founded as a totally independent international organization in 1999 is protecting the financial interests of the EU. [44] The Brussels-based institution's tasks are to protect the EU's budget from frauds, corruption, organized crime and related illegal activities. The execution of these -which are guides, not obligations-are done after inner and external governmental examinations, legislation and creating policies, through coordinating the member countries.

\section{The European Union's Judicial Cooperation Unit (Eurojust)}

The organization's task (founded in 2002, Den Hague) is optimizing the cooperation between the member countries' authorities and prosecutors, fostering the collaboration cross-border in the case of serious and organized crime, and elaborating EU legislation units for the virtuous and swift impeaching of the criminals. [45]

\section{Financial Crimes Enforcement Network (FinCEN)}

Founded in the Unites States of America, in April 1990, in the context of the Financial Ministry. The federal organization's seat is in Virginia; the European HQ is in Vienna. [46] The basic idea of its foundation was initially in order to move forward the American, later the international financial world's transparency and to elaborate, manage and supervise the anti-money laundering policies. Its activities, besides the traditional financial systems was extended to informal banking systems (e.g. hawala), and to suspicious transactions through virtual networks. Its motto is: “Follow the money!" Although its main activity is done in the

\footnotetext{
26 Antigua and Barbuda, Aruba, Bahamas, Barbados, Bermuda, the British Virgin Islands, the Cayman Islands, the Cook Islands, Curacao and Saint Maarten, Gibraltar, Guernsey, the Isle of Man, Jersey, Labuan, Macau (China), Panama, Samoa, the Terks and Caicos Islands, Vanuatu. [41]

27 The staff of Europol has no power to arrest, they attend specific matters as professionals.
} 
United States of America, but since it is supporting to form other countries' and organizations' effective anti-money laundering measures, furthermore it aspires to a tight collaboration in the area of global crime, thus having a major effect on the European Union institutions.

\section{Conclusion}

The parties fighting against money laundering and financing terrorism realized the fact that besides corresponding to the stricter security requirements - with increasing efficiency and last but not least evading sanctions - they mutually need each other, since this is the only way for them to be successful in the future. With the foundation of FATF, it defined and founded the global basis of the fight against money laundering, which activities were later extended to fight against financing terrorism and spreading mass destruction weapons-casting a shadow on our everyday life. To the initiative, since 2006, further 9 regional organizations have joined, committing themselves to fully enforce and execute the recommendations and standards, which result in a positive development in the past years. Their power and influence well reflects the fact that the FATF today consists of 37 members, 9 regional organizations and 198 jurisdictions, which closely cooperate with the United Nations, the Egmont Group, fostering the work of law enforcement authorities. ${ }^{28}$ Their global effect is increased further by the collaborating institutions and law enforcement authorities, which are not members of the FATF, but during their activities, they organically join the everyday war against money laundering and financing terrorism.

Since the FATF does not wish to accept new members, instead they support the creation of collaborative international organizations, working together with them. The regional organizations created this way-taking the local specialties, work methods and permissions into account - can stand against the criminals more efficiently and successfully. With the help of the FATF-elaborated standards, the members can utilize such unified methods, which help stand against money laundering and financing terrorism as a global coalition. The wide utilization of available capacities aspires to help unveiling, interrupting and finally freeze the financial backgrounds of terrorist and criminal organizations. During their activities, in order to keep up their credibility and show results-with taking the risks pro rata and efficiency into account-accountability, consistency, collaborations, sharing information and forming a unified thinking when utilizing the standards have become determinative requirements.

The fight against money laundering and financing terrorism is a never-ending process, which cannot be fully liquidated, but for every country's comprehensive interests, it is necessary to repel these with every legal means necessary. Thanks to the past years' successful collaborations, a significant number of countries and organizations have joined the fight, which — with adapting the standards — already have the skills and related base of knowledge, and help achieving successes when global action is taken. As we can see, the opportunities and conditions are available for the fight, the only question is, how can we utilize these resources efficiently in the future...

28 Note that the FATF consists of more jurisdictions overall, than the UN. [47] 
A. BUGYÁKI: The Most Significant International Groups...

\section{References}

[1] FATF Members and Observers. www.fatf-gafi.org/about/membersandobservers/ (Downloaded: 31.01.2017)

[2] OECD. www.oecd.org/about/history/ (Downloaded: 30.01.2017)

[3] History of the FATF. www.fatf-gafi.org/about/historyofthefatf/ (Downloaded: 31.01.2017)

[4] DUSIK S.: Pénzmosás. Belügyi Szemle, 483 (2000).

[5] MARTON B.: A pénzmosás megelőzése és megakadályozása. A tőke szabad áramlása. Európai Füzetek 39. Budapest: Miniszterelnöki Hivatal Kormányzati Stratégiai Elemző Központ, 2003.

[6] International Standards on Combating Money Laundering and Financing of Terrorism \& Proliferation -The FATF Recommendations. June 2017. www.fatf-gafi.org/media/fatf/ documents/recommendations/pdfs/FATF\%20Recommendations\%202012.pdf (Downloaded: 30.06.2017)

[7] Társaságiadó-kikerülés—Hibrid struktúrából adódó diszkrepanciák. Gazdasági és Pénzügyi Tanács, 2017. február 21. www.consilium.europa.eu/hu/meetings/ecofin/2017/02/21/ (Downloaded: 01.03.2017)

[8] FATF High-risk and Non-cooperative Jurisdictions. http://fatf-gafi.org/countries/\#high-risk (Downloaded: 20.07.2017)

[9] High-Level Principles for the Relationship between the FATF and the FATF-Style Regional Bodies. Paris: FATF, October 2012, updated February 2016. www.fatf-gafi.org/media/fatf/ documents/High-Level\%20Principles\%20and\%20Objectives\%20for\%20FATF\%20and\%20 FSRBs.pdf (Downloaded: 25.05.2017)

[10] 47 Members States. Council of Europe. www.coe.int/en/web/portal/47-members-states (Downloaded: 30.01.2017)

[11] Committee of Experts on the Evaluation of Anti-Money Laundering Measures and the Financing of Terrorism. www.coe.int/en/web/moneyval/home (Downloaded: 12.01.2017)

[12] A pénzmosás és a terrorizmus finanszírozása elleni fellépés nemzetközi háttere. Budapest: Nemzetgazdasági Minisztérium, 2014. http://ngmszakmaiteruletek.kormany. hu/a-penzmosas-es-a-terrorizmus-finanszirozasa-elleni-fellepes-nemzetkozi-hattere (Downloaded: 30.01.2017)

[13] PINTÉR B.: A pénzmosás elleni küzdelem nemzetközi szervezetei. Debreceni Jogi Mühely, X 2 (2013), 44-53. DOI: https://doi.org/10.24169/DJM/2013/2/3

[14] CFATF, Who Are our 25 Members? www.cfatf-gafic.org/index.php/who-are-our-25-members (Downloaded: 20.07.2017)

[15] Caribbean Financial Action Task Force. www.cfatf-gafic.org/index.php (Downloaded: 20.07.2017)

[16] 19 Aruba Recommendations. June 1990. www.imolin.org/imolin/cfatf19.html (Downloaded: 20.07.2017)

[17] Asia/Pacific Group on Money Laundering. www.apgml.org/ (Downloaded: 20.07.2017)

[18] APG Strategic Plan 2016-2020. Asia/Pacific Group on Money Laundering. 2016. www. apgml.org/documents/search-results.aspx?keywords=2016-2020 (Downloaded: 20.07.2017)

[19] APG Members \& Observers. www.apgml.org/members-and-observers/members/default. aspx (Downloaded: 20.07.2017) 
A. BUGYÁKI: The Most Significant International Groups...

[20] ESAAMLG Members and Cooperating Partners. www.esaamlg.org/mcp/index.php (Downloaded: 20.07.2017)

[21] Eastern and Southern Africa Anti-Money Laundering Group. www.esaamlg.org/ (Downloaded: 20.07.2017)

[22] ESAAMLG Strategic Plan April 2017-March 2020. www.esaamlg.org/documents_ storage/2017-6-7-13-42-13_esaamlg\%20strategic\%20plan\%202017-\%202020\%20(1).pdf (Downloaded: 20.07.2017)

[23] ECOWAS Basic Information. www.ecowas.int/about-ecowas/basic-information/ (Downloaded: 20.07.2017)

[24] GIABA, Member States. www.giaba.org/member-states/index_-1.html (Downloaded: 20.07.2017)

[25] Inter Governmental Action Group against Money Laundering in West Africa. www.giaba. org/ (Downloaded: 20.07.2017)

[26] GABAC Les membres. http://spgabac.org/les-membres/ (Downloaded: 20.07.2017)

[27] GABAC, About. www.fatf-gafi.org/pages/members/gabac.html (Downloaded: 20.07.2017)

[28] GAFILAT, Miembros. www.gafilat.org/content/observadores/ (Downloaded: 20.07.2017)

[29] Financial Action Task Force of Latin America. www.gafilat.org (Downloaded: 20.07.2017)

[30] EAG Members. www.eurasiangroup.org/members_eng.php (Downloaded: 20.07.2017)

[31] Eurasian Group on Combating Money Laundering and Financing of Terrorism. www. eurasiangroup.org/ (Downloaded: 20.07.2017)

[32] MENAFATF, Overview. www.menafatf.org/about (Downloaded: 20.07.2017)

[33] MENAFATF, Members. www.menafatf.org/about/Members-Observers/membersm (Downloaded: 20.07.2017)

[34] Egmont Group, List of Members. www.egmontgroup.org/en/membership/list (Downloaded: 20.07.2017)

[35] Egmont Group, About. www.egmontgroup.org/en/content/about (Downloaded: 20.07.2017)

[36] A Tanács határozata (2000. október 17.) a tagállamok pénzügyi hírszerző egységeinek az információcsere terén folytatott együttműködésére vonatkozó rendelkezésekről. EU-Lex, az Európai Unió hivatalos lapja, 2000. október 17. http://eur-lex.europa.eu/legal-content/ HU/TXT/?uri=CELEX\%3A32000D0642 (Downloaded: 01.05.2017)

[37] SZENDREI F.: A pénzmosás. (PhD-értekezés). Pécs: Pécsi Tudományegyetem, Államés Jogtudományi Kar, 2010.

[38] Egmont Group Hungarian Financial Intelligence Unit. www.egmontgroup.org/en/content/ hungary-hungarian-financial-intelligence-unit (Downloaded: 20.07.2017)

[39] FIU.net, About. www.europol.europa.eu/about-europol/financial-intelligence-units-fiu-net (Downloaded: 20.07.2017)

[40] GIFCS, History. www.gifcs.org/index.php/about/history (Downloaded: 20.07.2017)

[41] GIFCS, Members. www.gifcs.org/index.php/about/members-and-observers (Downloaded: 20.07.2017)

[42] GIFCS, Plenary Press Release. London, 25-26 April 2017. www.gifcs.org/images/ GIFCSApril2017PlenaryPressRelease.pdf (Downloaded: 20.07.2017)

[43] Európai Unió—Európai Rendőrségi Hivatal (Europol). https://europa.eu/european-union/ about-eu/agencies/europol_hu (Downloaded: 05.05.2017)

[44] OLAF, European Commission, European Anti-Fraud Office, Policy. http://ec.europa.eu/antifraud/policy/preventing-fraud_en (Downloaded: 05.05.2017) 
A. BUGYÁKI: The Most Significant International Groups...

[45] Eurojust, The European Union's Judicial Cooperation Unit. www.eurojust.europa.eu/Pages/ languages/hu.aspx (Downloaded: 05.05.2017)

[46] FinCEN, What We Do. www.fincen.gov/what-we-do (Downloaded: 05.05.2017)

[47] Speech on the Importance of the FATF Global Network. www.fatf-gafi.org/publications/ fatfgeneral/documents/moneyval-speech-importance-of-fatf-global-network.html

(Downloaded: 20.07.2017) 